UDC 316.7:378

Larissa TITARENKO,

Maria ZASLAVSKAYA,

Pargev AVETISYAN

\title{
ACADEMIC AND CORPORATE CULTURES IN MODERN UNIVERSITY (A CASE STUDY OF ARMENIA AND BELARUS)
}

\begin{abstract}
Any reforms of modern education in the context of the Bologna principles somehow connected with the fundamental academic values and freedoms that guarantee institutional autonomy and social integrity of the universities. At the same time, post-Soviet transformations of the higher education systems (HESs) often assume the introduction of the market-oriented approaches to meet the economic challenges that may contradict the traditional academic culture. On the basis of research data gleaned mainly from expert interviews in framework of case study in Armenia and Belarus, the authors analyze the ongoing transformations in HES with a focus on the features of implementation of academic freedoms in the context of existing contradiction between the new tendencies in higher education (marketoriented values, the entrepreneurial university model) and its classical humanistic model oriented to academic values, as well as to assess a possibility of coexisting academic and market cultures within the university. The authors reveal the contradictory attitudes to the assessment of the level of implementation of academic freedoms and to the possibility of combining academic freedoms with corporate culture in mentioned countries. Moreover, HESs needs the radical changes that would not destroy its fundamental culture and help to adjust universities to global challenges.
\end{abstract}

Keywords: academic freedoms, corporate culture, Bologna principles, higher education, reforms, entrepreneurial university, Armenia, Belarus.

Introduction

After the collapse of the Soviet Union, the post-Soviet countries have been searching for ways to establish their own educational systems under the new conditions of a dialectical unity between the challenges of globalization and the desire to strengthen their national identity and cultural traditions. These contradictory tenden- cies were manifested in the adoption in the academic discourse the term "glocalization" (R. Robertson) to stress the inseparability of the globalization and localization processes (Roudometof, 2016). The system of higher education absorbed these contradictory tendencies as relevant ones as post-Soviet countries joined several regional associations trying to combine their international principles and values with the national priorities. 
At the same time there was (and still is) a visible lack of a clearly articulated vision of philosophy of education to be applied to the national education practice (Bel'skiy \& Borovinskaya, 2019, p. 27). A big common problem is the lack of proper funding of the sphere of higher education. Other economic, political, managerial factors also impede the integration processes in education and the achievement of national priorities.

A complicated situation in higher education systems was reflected in the logic of making managerial decisions and reforms. On the one hand, reforms are aimed at mutual integration within the post-Soviet space. On the other hand, due to the reforms, the national systems of higher education have become a part of the European higher education space (Bologna process). Finally, processes of modernization and globalization should not be obstacles to preserve the national cultural specifics and local traditions of each country.

The process of reorganizing higher education at the institutional level in accordance with the Bologna principles takes place in almost all post-Soviet countries. The Bologna principles are quite clearly defined in several documents ${ }^{1}$. However, in some countries, they are mostly reduced to the introduction of the two-level education system, credit system, quality control of education, and academic mobility that has a controversial impact on the development of HES in some post-soviet countries. For example, one of the consequences of such type of reforms is a brain drain.

See for example Bologna Declaration of 19 June 1999. Joint Declaration of the European Ministers of Education. Retrieved January 25, 2015 from: https://www.eurashe.eu/.../bologna_1999 bolognadeclaration.
On the one hand, the straightforward implementation of education reform technologies and the pursuit of formal Bologna indicators do not prevent the national HES from the new problems and do not automatically bring effective development changes. On the other hand, the new technological changes in the economy "dictate" the technocratic requests to the national HESs (Ivahnenko \& Attaeva, 2019, p. 22). This is common not only for the post-Soviet region. In the EU countries participating in the Bologna Process, the process of unification the sphere of higher education is viewed as recommended but not imposed, and some principles are implemented with limits ("European Commission/ EACEA/Eurydice", 2018).

The topic of our research relates to modern universities and their modernization in Armenia and Belarus within the context of the Bologna agreements under the current conditions of globalization. The research questions devoted to the specific manifestations of corporative culture within the modern HES in these two post-Soviet countries and its relation to academic culture are discussed. We examine the existing discourse about the ability of higher education in Armenia and Belarus to survive under conditions of the market. The research questions are discussed from the angle of a humanistic approach to higher education as a social institution in the public sphere.

\section{Method}

Our case study includes the systems of higher education in Armenia and Belarus that signed the Bologna agreements in order to modernize their spheres of higher education and improve their level of competitiveness in the global 
educational market.

The research was based on the expert interviews made in summer of 2018 in Belarus with more than 20 representatives of the HES and in 2018-2019 in Armenia with more than 25 experts. A targeted sample was used in Belarus; in Armenia, this type of sample was combined with a snowball one. Interviewees had to identify the existing tendencies of the reforms in HESs in these countries.

Our research assumed that the experts in the HES in each country would assess not only the implementation of academic values but also express their views on some other issues of reforms and evaluate features of modern HESs in their countries. Additionally, the analysis of documents was used as well as focus groups with representatives of the HESs to investigate their attitudes about the Bologna reforms.

The selection of these two post-Soviet countries for comparison was determined by the differences in the implementation mechanisms of the Bologna agreements in their HES. As the period of time for the implementation of Bologna reforms in these two countries was different, it was reasonable to compare whether the attitudes to the reforms and the results would also differ.

\section{Implementation of the Academic Values and Freedoms}

The first research question was related to the academic culture within the Bologna principles. The Bologna Declaration includes such principles as academic freedom, institutional autonomy, accountability, social integrity and the like. They are not only a part of the numerous
Bologna documents ${ }^{2}$, and they are based on the UNESCO documents on education. The Council of Europe also adopted documents on the research mission of universities in 2000 and a recommendation on the responsibility of public authorities for academic freedom and institutional autonomy in 2012.

It is known from many types of research that different countries do not always apply the academic freedoms and academic culture into the educational and scientific practice because freedom of research can bring results that are not favourable for the particular government interests, freedom of speech can disclose the truth in some politically touchy cases, and freedoms of professional unions can be against the corporate interests in a particular country (see, for example, Doumani, 2006). Although both Armenia and Belarus are members of the Bologna system, they joined it at a different time: Armenia in 2005 and Belarus in 2015. So, the countries have a different experience in the implementation of the Bologna principles and face different obstacles in this process depending on the sociopolitical and economic conditions of each country. The core academic values that are in line with the Bologna agreements include the traditional academic values: academic freedoms, social responsibility, institutional autonomy, selfgovernance, the free election of the academic authorities, etc. However, some of these values are still valid only on paper. For example, according to our case study, the common practice is that academic personnel for several leading positions within the university in Belarus are ap-

2 See Bologna Declaration of 19 June 1999. Joint Declaration of the European Ministers of Education. Retrieved January 25, 2015 from: https://www.eurashe. eu/.../bologna 1999 bologna-declaration. 
pointed by the higher administration and not elected. It leads to the fact that these top-level staff persons (the deans, vice-rectors, rectors, etc.) are not responsible and not accountable to the academic community but only to the administration.

In modern educational discourse both in Armenia and Belarus the Bologna requirements to promote and support the democratic culture, freedoms of speech and freedom of research, right to teach in accordance with their scientific approaches, to join the professional unions and protect their professional values described in the international documents ${ }^{3}$ are perfectly circulated. At the same time, the new editions of the Statutes of several institutions of higher education (HEI) in these countries already accepted the articles that somehow restricted traditional democratic values (for example, the appointment for the high staff positions, the lack of their accountability before the academic community, rectors' right to terminate the staff labor contract at any time for any reason not even mentioned in the Statute (Dunaev, 2018). This situation manifests a break with the previous classical model of the university as an independent social institution of a society, a community of intellectuals devoted to search the truth: whether this truth is "useful" and "profitable" for the political authorities and for the market or not.

The results of our research indicate a similar situation in Armenia and Belarus in some spheres. Many respondents mentioned cases of violation of academic rights and freedoms (freedom to teach on their own program, censorship,

See General Comment (1999). No. 13: The Right to Education (Art. 13 of the Covenant) 12/1999/10. Retrieved September 19, 2018 from: https://www. refworld.org/docid/4538838c22.html. the imposition of state ideology in the programs, etc.). They referred to the cases of plagiarism among the academic staff that were not even morally assessed as unacceptable at the universities. The respondents mentioned also the situation of lack of enough attention to the problem of academic values in the university environment. It is interesting to note that the university officials in both countries often somehow justified the decisions made by the Ministry in regards to the reforms whether these decisions were really good for the academic community or not. They also justified some restrictions of academic freedoms. For example, a Belarusian vice-rector said that it is safer to appoint the rectors and not be dependent on the academic communities that are often too critical and too liberal (Titarenko \& Zaslavskaya, 2019, p. 68). As for the increased tendency of rectors to fire the university staff, such cases were known in Belarus (some university scholars were fired after publishing a critical book). This is a clear case of impairment the academic integrity (Dunaev, 2018, p. 41). The academic tenure can protect academic freedoms of the staff; however, it does not everywhere exist in Armenia and Belarus and makes the position of critically oriented academic staff under a threat of being somehow punished for their speech or research. In the case that academic values would be subordinated to corporate ones, there will be no more problem of this kind: a business corporation is based on the loyalty of its members.

In Belarus the situation with academic freedoms and institutional autonomy was accessed slightly worse than in Armenia: the concept of academic freedoms does not exist in the official 
documents on the sphere of education ${ }^{4}$, although adoption of the Bologna principles automatically meant that Belarus would follow the legal principles Magna Charta Universitatum ${ }^{5}$. However, they are still not guaranteed in the official documents on education. Only the Constitution guarantees the fundamental rights to all the citizens, while Statutes of several HEIs have limitations (Dunaev, 2018, p. 80). What is even worse is that the European common space of higher education also experiences attacks from the market that may decrease the institutional autonomy and limit other academic values in the HES everywhere. The mechanism of this trend is functioning in Armenia.

Collective management bodies of the universities currently have to include more social partners from outside the particular HEI. As a result, a binary structure of the university management is increasingly widespread: it distributes power between the internal board (Senate) and the external one (the governing board). This way, the external stakeholders of the higher school (representatives of state and private corporations, government administrators, etc.) get more and more power in the academia. It becomes clear that "this new configuration of institutional autonomy is a challenge to the traditional values and models of academic democracy" (Dunaev, 2018, p. 80). This practice is not common for

4 See: Zakon (1991) Respubliki Belarus' "Ob Obrazovanii" (Law of Republic of Belarus on Education, in Russian), 29.10.1991, №1202-XII. Retrieved March 16, 2016 from: http://pravo. levonevsky.org /bazaby zakon/text39/index.htm.; Zakon (2007) Respubliki Belarus "O vysshem obrazovanii" (Law on Higher Education of the Republic of Belarus, in Russian), 11.07.2007, № 252-3. Retrieved September 24, 2015 from: http://www.pravo.by/pdf/2007-171/2007-171 (004-028).pdf.

5 See: Magna Charta Universitatum. Retrieved January 16, 2018 from: http://www.magna-charta.org/res ources/files/the-magna-charta/russian-1.
Belarusian HES where all the important decisions on higher education are made not by the HEIs, but the state power. However, this is already common for Armenia where universities have Boards of Trustees partly appointed by the state leadership, and whose power can be stronger than the power of Council of University. This means that the market challenges are gradually changing the orientations of higher education regardless of the formal documents, principles, and democratic university traditions. Today the new conditions in many European countries demand from the universities more flexibility and openness to the market so that the universities will gradually meet the criteria of economic efficiency similar to business corporations. This is a tendency that becomes visible in European and other advanced states even more than in such post-soviet states as Armenia or Belarus.

\section{Corporate Culture and the Entrepreneurial University}

Our second research question relates to the new model of the university (at least, new for the HES in Armenia and Belarus) - a model of the entrepreneurial university. The question is whether this model can be accepted by the academic staff in Armenia and Belarus, and if so whether it will be able to really improve the whole system and make it closer to the market? As there is not enough research on this matter and not enough knowledge among the university staff, we made our research on the basis of the analysis of scientific literature in the region, the available official documents on this matter, and some information from the experts. It was pilot research that discovered the complexity of this issue and lack of clear decisions. As both coun- 
tries are not rich enough, their spheres of higher education are not properly funded by the state. Governments want to make the HESs closer to the market and make higher education a profitable sphere. Therefore, the process of straightforward introducing corporate culture to the universities and imposing the model of the entrepreneurial university has started.

The current crisis in the sphere of higher education is not a local one. It started many years ago at the end of the previous century and was articulated by several famous scholars. For example, Bill Readings (1997) connected this crisis of the mission of the classical university as a social institution and a community of intellectuals searching for truth with the decline of the nationstate and national cultures under conditions of globalization. Readings stated that currently, a university had to become a corporation driving for excellence rather than to pursue the academic values and search for the truth. Currently, more than 20 years later, regardless of the fact, that nobody would agree with the decline of the nation-states, especially in the post-soviet space, a similar crisis of higher education has become a dramatic reality, and the same issue of the mission of the university arose. The reason behind this crisis is the globalization that assumes that the nation-states must be economically competitive in order to survive, and the "society of knowledge" should serve for this economic aim. The idea expressed by Readings that the new University of Excellence is "a corporation driven by market forces, and, as such, is more interested in profit margins than in thought", has been absorbed by many ex-Soviet political leaders and implemented in their educational policy. Therefore, the academic intellectuals (especially philosophers of education) in post-Soviet countries have to think about possible ways out of this crisis and the new arguments to defend the university mission and traditional academic values.

At the end of the previous century, several scholars from Western Europe and the US already researched this model. In his well-known book titled "The Creation of an Entrepreneurial Universities. Organizational Transformation Directions" B. Clark provided five examples of such universities researched in the 1990s. Clark (1998) made his case studies in some provincial universities in five countries in order to show how the universities within the EU that have not been among the best ones have found the ways to improve their competitiveness. Clark did not propose this model as the only one that is possible for the future. For him, this model was suitable mainly for technical universities with the previous experience of good ties with business and corporate culture. Clark did not place in opposition to academic and corporate cultures. However, corporate culture, in his view helped these universities to become more rational and produce material products to sell on a market.

Currently, the entrepreneurial model is also not the only one in advanced western countries. There are many different models with different philosophies of education, adjusted to the national and cultural traditions, needs, previous experience, etc. For example, in the model of the "innovative university" academic culture is considered as a harmonious part of corporate culture (Christensen \& Eyring, 2011).

However, the situation related to the postsoviet commercialization of universities is extremely problematic. Overall, in Armenia around $80 \%$ and in Belarus more than $50 \%$ of the students have to be stakeholders in their own education, i.e. pay for their studies (some years ago the 
number of those who paid was even higher) ${ }^{6}$. Despite the fact that the commercialization of the higher education in the post-Soviet countries has been rapidly developing since the 1990s, these countries can't compete with the EU countries in funding research and teaching. Thus, according to the "continental model", like in Germany, universities are financed mainly from the state budget and offer their students free education. According to another model ("Anglo-Saxon"), like in the UK, universities are funded through a complex structure of taxation and encouraging patronage. In both cases, they have enough funds for study and research and still enjoy an academic culture.

When the students in Armenia or Belarus have to pay for their education, they often lose motivation to learn and do research: they simply want to buy a diploma. As the educational practice in Armenia and Belarus demonstrates, the consequences of this commercialization of higher education have been destructive for many young people: they have lost the motivation to learn and study. When a person is not interested in increasing his/her cultural capital, he/she wants an economic equivalent of economic investment. As Erich Fromm (2013) described, such person wants to get economic results as if it is a deal on the market: "No interest in the subjects studied or in cognition and comprehension as such, but knowledge of what raises the ex-

See SCRA (2018). Sotsial'no-ekonomicheskoe polozhenie Respubliki Armeniya v yanvare-marte 2018 g. (The Socio-Economic Situation of the Republic of Armenia in January-March 2018, in Russian). Statistical Committee of RA. Retrieved May 15, 2019 from: https://www.armstat.am/file/article/sv 03 18r_5190.p df.; NSC (2018). Statisticheskii Ezhegodnik Respubliki Belarus (Statistical Yearbook of the Republic of Belarus, in Russian). Minsk: National Statistical Committee. change value is the motive for obtaining a broader education" (pp. 78-79).

The other side of commercialization is a university professor who is losing the previous status of a scholar/researcher and turning to a seller on a market where knowledge has become a commodity. Her/his social prestige is disappearing, while as a teacher, he/she is losing their moral mission as an educator. This situation is already typical for some universities throughout the world. More than a decade ago Italian scholars pointed out that "the rigid application of the principles of productivity, the functioning of the university as an enterprise, the predominance of a managerial approach to a purely cultural and cognitive one, can quickly lead to a crisis in some disciplinary areas" (Bratti, Checchi, \& Blasio, 2008).

The results of our comparative analysis showed the existence of a deep contradiction between the two different cultures within the systems of higher education. Most universities would like to follow the traditional missions and rely upon state finance, while the government demands the HES to be closer to the economic needs and business. As a consequence of such demands, a model of "university 3.0" was introduced in Belarus, and a new concept of "down to practice" higher education was officially developed by the university administrators (Kolesnichenko, 2019). The main idea of this concept is the necessity of adjustment of the academic culture to the demands of the corporate culture. In this regard, universities are forced to change their mission and subordinate their scientific and educational goals to the market.

In Armenia, the idea of bringing businessmen to the Boards of Trustee or the Council of the University is actively implemented (Titaren- 
ko \& Zaslavskaya, 2019, p. 59). Our research confirms that a prevailing pragmatic attitude towards obtaining the immediate economic profit by any means prevails, as funding is the key (Titarenko \& Zaslavskaya, 2019, p. 47). The research also revealed that the Armenian HES was developing extremely unevenly: in some areas, the reforms were rapidly carried out (the introduction of a credit rating system), and other areas still did not introduce reforms (for example, the development of educational programs). This imbalance leads to the fact that formal reformation often takes place so that a real vision of transformations is not clearly perceived. In the conditions of the loss of academic freedoms, the administration wants to combine education and research with business, invite new stakeholders, make study programs open to the practical demands and finally employ the university graduates to the new economic branches. There is a search for the appropriate ways of combining the two different approaches to the higher education and two different systems of culture in order to make the universities more related to the market requirements and therefore create a new type of entrepreneurial university.

Practically speaking, it is not clear how to combine different value systems together without the domination of market values over the academic freedoms. Theoretically, it is clear that a loss of academic freedoms and values will mean a break with the Bologna principles. This challenge will destroy the classical model of a university with its traditional academic culture. Still, the anticipated goals of increasing competitiveness and attracting new stakeholders to academia may not be reached without full subordination of higher education to market goals and the corporate culture.
Discussion

The major practical question under research is how to make modern university competitive and find new sources of finance. If we put this question in the framework of methodology of education, then we have to understand whether it is possible to remain true to the Bologna principles and academic freedoms, follow the traditional missions of the university and include the corporate culture into the higher education. These discourses may differ. Thus, on a pragmatic level, a model of the entrepreneurial university has been supported by the scholars from the most advanced universities like, for example, the Higher School of Economics (Chepurenko, 2018). However, many scholars are very sceptical and do not support the expansion of the corporate culture (Zborovskiy, Ambarova, \& Shuklina, 2017; Kolycheva, 2019). Theoretically speaking, the scholars found out that the fundamental basis of this model is the postmodern theory of McDonaldization (Erovenko, 2019). The author of this theory, G. Ritzer (2009) clearly argued that it is destructive for society, and it can erode the human being. A special theory of McDonaldization of higher education was later developed and became well known in the US in the early 2000s (Hayes \& Wynyard, 2002). Methodologists and philosophers of education in post-soviet states who support the transformation of a university into a corporation can learn from this theory and understand that its full implementation can manifest the end of classical education. The long-term consequences of commercialization and marketization of the university are currently unclear for a personality and a state. Unfortunately, Armenian or Belarusian social philosophers do not focus enough on this im- 
portant theme.

Meanwhile, under the contemporary dominance of a rational economic approach to the state educational policy, the social institution of higher education is also positioned by the administrators and politicians as subordinated to the economy (either on a global or national level), especially the «knowledge economy» which is understood as the creation of products within the university and its market implementation. The governments consider the "usefulness" of education as a means to prepare "a good labour force" for the new digitalized economy. Thus, according to this approach, a high number of students at a particular HEI is an indicator of good quality of education. Demands of "industry 4.0 " or a digitalized economy dictate the goals in the development of other social institutions regardless of their traditional social roles and missions in society and even regardless of the international agreements signed by the government earlier in regard to the particular social institution.

Our research showed that in the context of commercialization of the HES that is officially positioned as an important modern tendency within the ongoing reforms, there is a deep concern how to combine education, science and business values under the roof of an entrepreneurial university model. Unlike the administrators, many scientific researchers and university professors think that the combination of academic and business values will inevitably make the HES subordinated to the market. Hence, traditional academic culture can be destroyed and substituted by the entrepreneurial culture, and the social institution of higher education will disappear from the public sphere as an actor. HES will not even stay under the supervision of the state. Instead, a new market-oriented actor will appear with a culture, that will be totally corporate and which actions will be determined by the profit motive. This is a real threat that currently, the state administrators might not even understand. Currently, they mainly worry about lack of money to finance the HES and try to find additional sources beyond the state budget. That is why the Ministries of Higher Education support an idea of the entrepreneurial university and assume that "university 3.0" would unite three missions: traditional university's mission to educate the young people as "good citizens," prepare good specialists for the national economy, and anew mission to produce and sell the marketable products. A part of this corporate philosophy is to connect the employers with universities: the former would be members of the universities' boards and determine which kind of specialists they would need, and the latter would adjust the curricula to the market requests. Although Clark (1998) was not a philosopher, he viewed an entrepreneurial university within the framework of a particular paradigm: "entrepreneurial" embraced the "entire universities", would provide them with resources and infrastructures and "enact an up-market climb in quality and reputation" (pp. 3-4).

Clark anticipated that the traditional academic staff at the classical universities would not accept the idea of the entrepreneurial university as it contradicts the university values and especially academic integrity. He anticipated that the "entrepreneur might continue to be a negative term in the minds of traditional academics, all the more so after they have seen hard managerialism in action" (Clark, 1998, p. 148). Clark believed that traditional academic communities do not have academic integrity because they consist of different faculties and have different scientific 
interests. Clark ignored that traditional academic values (including integrity) relate to the academic institution and the academic community as a whole: these values exist beyond the level of professional interests; they are parts of the scientific ethos that is common for all who belongs to this social institution. That is why currently, these academic values are parts of a democratic culture shared by intellectuals within and beyond the academia/university itself, and they are an essential part of Bologna principles.

Half a century ago, a German social philosopher Jurgen Habermas argued that modern society has three quite different spheres: the state, the market, and the public. Each of these spheres has and pursues its own interests, so that if any of them is weak, then the two others would exploit it and even colonize it (Habermas, 1993). Traditionally, in European history, the social institution of higher education has belonged to the public sphere. Intellectuals often used the university to elaborate on the famous concepts of the nation-state, national culture, modernity, and the like. The state financed the higher education assuming that universities would teach the youth the values and modern knowledge that are necessary to support the proper functioning of the state and the moral standards in a society. Universities had institutional autonomy and the right to elect their staff. Neither the state nor the market could dictate to the universities what to study and how to teach. Classical universities (such as Humboldt University in Berlin) followed the academic culture and took care of university freedoms and rights to search for truth. The Bologna Declaration follows this academic heritage and supports the institutional autonomy of the universities. Such autonomous existence of higher education among the other different types of institu- tions in society helped to support societal consensus for a long time. Many EU societies still follow this idea, trying to keep the social harmony between the state, the public sphere, and the market.

This is not the case for the post-soviet states. First, here, the state always dictates the rules for the sphere of higher education because the state provides financial support for the universities. Second, the state, being economically dependent on the national or global market, tries to work in line with the market as long as it does not touch its own interests. Third, the state considers the HES as a subordinated sphere because the state provides financial support for it. Therefore, the HES is responsible for the state's needs to educate good citizens, defend the national priorities, develop the ideas of national identity, traditions, etc. If the post-Soviet state would increase the role of the market (including financing research at the university) in the sphere of higher education, the HES might be turned into a market-dependent unit. Its future development will be unpredictable and mostly dependent on market interests. Only when the universities belong to the public sphere of a society, they can produce ideas and concepts that are necessary for the nation-state. If the universities follow the corporate culture and search for profits, they would pursue the vested interests similar to the business enterprises.

Recently Armenian scholars carefully researched the mechanisms of harmonization of university education and workplace requirements. They assumed that "the significant involvement of employers in the management and faculty councils will also have a positive impact on the improvement of the law-making practices and their role" (Hovhannisyan, H., Hovhannis- 
yan, Hovh., \& Petrosyan, 2018, p. 51). At the same time, it is necessary to stress the controversial character of the interrelations between the academic and commercial values that belong to the different sets of culture - academic and corporate; therefore, a possible subordination of the universities to the market would be the end of the process of higher education as formation of a personality with a broad world outlook and conscious responsibility for social behaviour. Therefore, we agree with a position that "it is expedient to revive the goals of the educational system determined by the national culture, the most important of which is the education of man as a spiritual and political being" (Mirumyan, 2018, p. 53).

\section{Summary}

The systems of higher education of Armenia and Belarus have to solve the complicated problems of meeting the global and national challenges. They pursue several reforms that sometimes conflict with each other. One of the unsolved problems is a search for a non-controversial balance between the classical university and traditional academic values, on the one hand, and the entrepreneurial university and corporate culture, on the other. These are two different cultures belonging to different sets of philosophical norms and principles: humanistic and marketoriented.

Probably market-oriented reforms of the HES can make education more profitable. Some researches confirm that corporate culture contributes to the improvement of competitiveness of the universities (Trotsuk \& Suhoverova, 2018). Meanwhile, it is difficult to expect that business would pay for economically unprofita- ble areas of science and education, which, however, have a great potential for development and future implementation in practice. However, science and education - these are areas of social functioning, the development of which is not always unambiguously predictable. The social institution of higher education belongs to the public sphere and can't serve commercial interests as its primary goal. Otherwise, the classical model of the university and related academic culture would be destroyed.

Many researchers in the sphere of higher education currently recommend universities to develop new forms and mechanisms to meet the market's demands that can be practically useful and help to bring the HES closer to the market. However, our research was focused not on the practical recommendations but on the assessment of the current reforms and the problems within the higher education. We discussed the results within the theoretical framework of democratic values and classical mission of the university as a part of the public sphere in society. Reforms in education can help to create conditions for the non-stop education of students, graduates, and specialists of different level to meet the new and changeable workplace requirements (Titarenko $\&$ Zaslavskaya, 2019). The new innovative mechanisms will relate to the improvement of the educational practice. As for the philosophy of education, it has to remain independent from the market expansion and provide the basis for the academic norms, values and principles that are necessary to keep the higher education institutions within the public sphere. HES may coexist and communicate with the market, but it must not be totally subordinated either to the market or to the state.

However, as both countries are relatively 
poor and their sphere of higher education is not properly funded, governments want to make the systems of higher education closer to the market. In order to make higher education a profitable sphere, the process of introducing to the universities corporate culture and imposing the model of the entrepreneurial university has started, although for a democratic academic culture this tendency might be a pitfall.

Moreover, when the academic culture of a modern university in post-Soviet countries is often limited by the administrative actions, that is especially the case in regard to the implementation of academic freedoms, several problems associated with the straightforward implementation of corporate culture may cause unpredictable consequences.

\section{REFERENCES}

Bel'skiy, V. Yu., \& Borovinskaya, D. N. (2019). Aktual'nye modeli razvitiya obrazovaniya: podkhody i principy ikh realizatsii (Actual Models of Education Development: Approaches and Principles for their Implementation, in Russian). Social and Humanitarian Knowledge, 2, 27-38.

Bratti, M., Checchi, D., \& de Blasio, G. (2008). Does the Expansion of Higher Education Increase the Equality of Educational Opportunities? Evidence from Italy. Labour: Review of Labour Economics and Industrial Relations, 22 (s1), 53-88.

Chepurenko, A. Yu. (2018). Marx v universitete 3.0? (Marx at university 3.0?, in Russian) Sociological research, 5, 26-34.
Christensen, C. M., \& Eyring, H. J. (2011). The Innovative University: Changing the DNA of Higher Education from the Inside Out. San Francisco: Willey.

Clark, B., (1998). The Creation of an Entrepreneurial Universities. Organizational Transformation Directions. Oxford: Pergamon Press.

Doumani, B. (Ed.) (2006). Academic Freedom after September 11. New York: Zone Books.

Dunaev, V. (Ed.) (2018). Belaya kniga. Evropeiskie perspektivy belaruskogo vysshego obrazovaniya (White Book. European Perspectives of Belarusian Higher Education, in Russian). Vilnius: VŠ̆ «Socialinès ir politinès ekspertizès agentūra».

Erovenko, V. A., (2019). Socialnyi protsess "makdonaldizatsii" na primere transformatsii matematicheskogo obrazovaniya (Social Process of "McDonaldization" on the Example of the Transformation of Mathematical Education, in Russian), Alma-Mater, 2, 15-19.

European Commission/EACEA/Eurydice (2018). The European Higher Education Area in 2018: Bologna Process Implementation Report. Luxembourg: Publications Office of the European Union. Retrieved April 20, 2019 from: https:// eacea.ec.europa.eu/national-policies leurydice/sites/eurydice/files/bologna_i nternet 0.pdf.

Fromm, E., (2013). Man for himself: An Inquiry into the Psychology of Ethics. New York: NY Open Road Integrated Media. 
Habermas, J., (1993, Spring). Otnosheniya mezhdu sistemoi i zhiznennym mirom $v$ usloviyax pozdnego kapitalizma (The Relationship between the System and the Life World in Terms of Late Capitalism, in Russian). THESIS, 1(2), 123136.

Hayes, D., \& Wynyard, R. (Eds.) (2002). The McDonaldization of Higher Education. USA: Greenwood Press.

Hovhannisyan, H., Hovhannisyan, Hovh., \& Petrosyan, A., (2018). Young Professionals' Labour Market Integration Issues in Armenia: A Case Study with Special Reference to Alumni of Armenian State Pedagogical University. WISDOM, 2(11), 42-52. https://doi.org /10.24234/wisdom.v11i2.225

Ivahnenko, E. I., \& Attaeva, L. I. (2019). Vysshaya shkola: vzglyad za gorizont (High School: a Look beyond the Horizon, in Russian). Higher Education in Russia, 3, 21-34.

Kolesnichenko, S., (2019). Zachem Belarusii universitet 3.0? (Why does Belarus Need University 3.0? in Russian). Retrieved January 8, 2019, from http://www.zautra.by/art.php?sn nid=2 9965.

Kolycheva, A. (2019). Protivostoyanie akademicheskikh sotrudnikov $i$ administrativnoupravlencheskogo personala $v$ sovremennom universitete (Opposition between Academic and Administrative Staff in Modern University, in Rus- sian). Alma-Mater, 1, 76-79.

Mirumyan, R. A., (2018). Education in the "Bending" of the Modern Political Landscape. WISDOM, 2(11), 53-65.

Readings, B. (1996). The University in Ruins. Cambridge and London: Harvard University Press.

Ritzer, G., (2009). The McDonaldization of Society. Los Angeles: Pine Forge Press.

Roudometof, V., (2016). Glocalization: A Critical Introduction. London and New York: Routledge.

Titarenko, L. G., \& Zaslavskaya, M. I. (Eds.) (2019). Modernizatsiya sistem vysshego obrazovaniya Belarusi i Armenii v kontekste Evraziiskoi i Evropeiskoi integratsii (Modernization of Higher Education Systems of Belarus and Armenia in the Context of Eurasian and European Integration Processes, in Russian). Minsk: BGU.

Trotsuk, I. V., \& Suhoverova, D. V. (2018). Korporativnaya kul'tura kak instrument povysheniya konkurentosposobnosti vuzov (Corporate Culture as an Instrument of Growth of the Competitiveness of the Institutions of Higher Education, in Russian). Higher Education in Russia, 27(11), 44-54.

Zborovskiy, G. E., Ambarova, P. A., \& Shuklina, E. A. (2017). Sushchestvuet li sistema vysshego obrazovaniya $v$ Rossii? (Does the System of Higher Education Exist in Russia? in Russian). Sociological Research, 11, 76-86. 